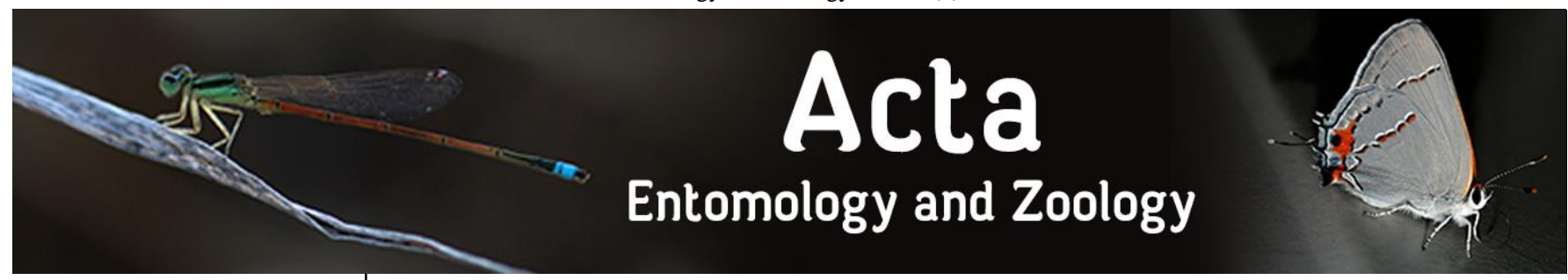

E-ISSN: 2708-0021 P-ISSN: 2708-0013 www.actajournal.com AEZ 2020; 1(1): 26-30 Received: 05-09-2019 Accepted: 15-10-2019

\section{Ismail Hassan}

Department of Biological Sciences, Faculty of Science, Bauchi State University, P.M.B 65 Gadau, Bauchi State, Nigeria

\section{Jibrin Nasiru Disina} Department of Biological Sciences, Faculty of Science, Bauchi State University, P.M.B 65 Gadau, Bauchi State, Nigeria
Corresponding Author: Ismail Hassan Department of Biological Sciences, Faculty of Science, Bauchi State University, P.M.B 65 Gadau, Bauchi State, Nigeria E-mail: ihassan408@gmail.com

\section{Indigenous knowledge of termites control methods in five farming communities in Gadau district Bauchi state Nigeria}

\author{
Ismail Hassan and Jibrin Nasiru Disina
}

DOI: https://doi.org/10.33545/27080013.2020.v1.i1a.5

\begin{abstract}
This study was conducted in five farming communities selected at random in Gadau district, Itas/Gadau Local Government, Bauchi State Nigeria. The research was aimed at identifying suitable and sustainable indigenous methods adopted by the local peasant farmers for termite control in which semistructured questionnaires were administered to 20 farmers in each of the selected five communities who practice indigenous termite control methods. A total of 100 farmers who had applied various indigenous treatments on their crop fields against termites' infestation were interviewed. 81 termites' species, which varied in presence at each locality, and five termite prevention and control methods were identified in the area: (i) Direct pouring of water on the termite nest (ii) application of wood ash (iii) Application of a mixture of salt and Shea butter residue (iv)Mixture of cow urine and paper and (v) Application of Chemical (DDT). Application of wood ash was found to be the most common method used by the farmers. Despite their well-known role as pest, termites are considered important in the area because they provide necessary ecosystem services.
\end{abstract}

Keywords: Termite, farmers, wood ash, shea butter, pest control, gadau

\section{Introduction}

Termite infestation is prevalent worldwide especially in the tropics where distribution, extent of spread, problems and constraints results in livelihood threats particularly among rural small-scale farmers ${ }^{1}$. The ever-growing interest in sustainable agriculture and food security on the African continent highlights the need for a more balanced approach to termite control that will prevent serious ecological damage and loss of ecosystem services provided by termites whilst using the available resources without exhausting them.

Termites are abundant and diverse throughout the world with about 660 species out of the total of 2600 species found in Africa ${ }^{[2]}$. In Nigeria, 86 species are found, which belong to 38 genera, comprising of mound building and dry wood termites ${ }^{[3]}$.

In Nigeria, some species (e.g. Macrotermes, Microtermes and Odontoter-mes species) cause widespread damage to crop seed-lings whilst others (e.g. Ancistrotermes, Allondoter-mes and Pseudacanthotermes species) cause localized da-mage to forest trees, rangelands, food crops and other natural resources ${ }^{[4]}$

Damage caused by termites is greater during periods of drought than during the periods of regular rainfall ${ }^{[5]}$. The problem of termite infestation can have several effects such as agronomic, economic, or social constraints. The agronomic influence includes the role of termites as pests and ecosystem engineers; whereas, the economic aspect involves the destructive tendencies of termites due to their foraging activities on plants and wood products which cause economic hardship to individual producers ${ }^{[6]}$

In some African countries, information on economic losses is available, for example, in Kenya and Tanzania up to $30 \%$ damage has been recorded ${ }^{[7]}$, while in Ethiopia $60 \%$ damage has been recorded Also, inter-views held with famers in south western Nigeria revealed that up to $100 \%$ damage can occur on maize production. Chemical control of termites in plantations and farms is expensive and require skilled labor and may not be effective in all cases ${ }^{[8]}$. The problem of termite infestation can have several effects such as agronomic, economic, or social constraints.Termites are one of the major agroforestry pests in the tropics causing substantial economic losses; losses ranging from $50 \%$ to $100 \%$ have been reported. Chemical control of termites in plantations and farms is expensive and require skilled labor and may not be effective in all cases ${ }^{[8]}$. 
The excessive application of termiticides causes environmental pollution and may result in the death of nontarget organisms, which necessitated the ban of some chemical control measures. Several indigenous methods are used by farmers to prevent and control termites in Nigeria. They include wood ash, sand, toads and shell/scallop of tortoise [9]. Some of these methods are evaluated and documented for the southern belt of the country only. Information generated on the indigenous knowledge of termite management within the zone will be vital for priority setting and development of pest management strategies that meet local needs ${ }^{[9,10]}$.

As there are several indigenous methods used by farmers to prevent and control termites in this particular area, the purpose of this research is to provide the indigenous and reliable knowledge on controlling termite infestation in five farming communities in Gadau District.

The aim of this study was to identify suitable and sustainable indigenous methods used by local farmers that best fit the biophysical, economic and socio-cultural conditions of termite control.

\section{Materials and Methods}

Study area Gadau is situated in Itas Gadau Local Government Area Bauchi State Nigeria, Gadau is located in the West Africa time zone latitude and longitude of $11.8328495,10.1661239$ respectively.

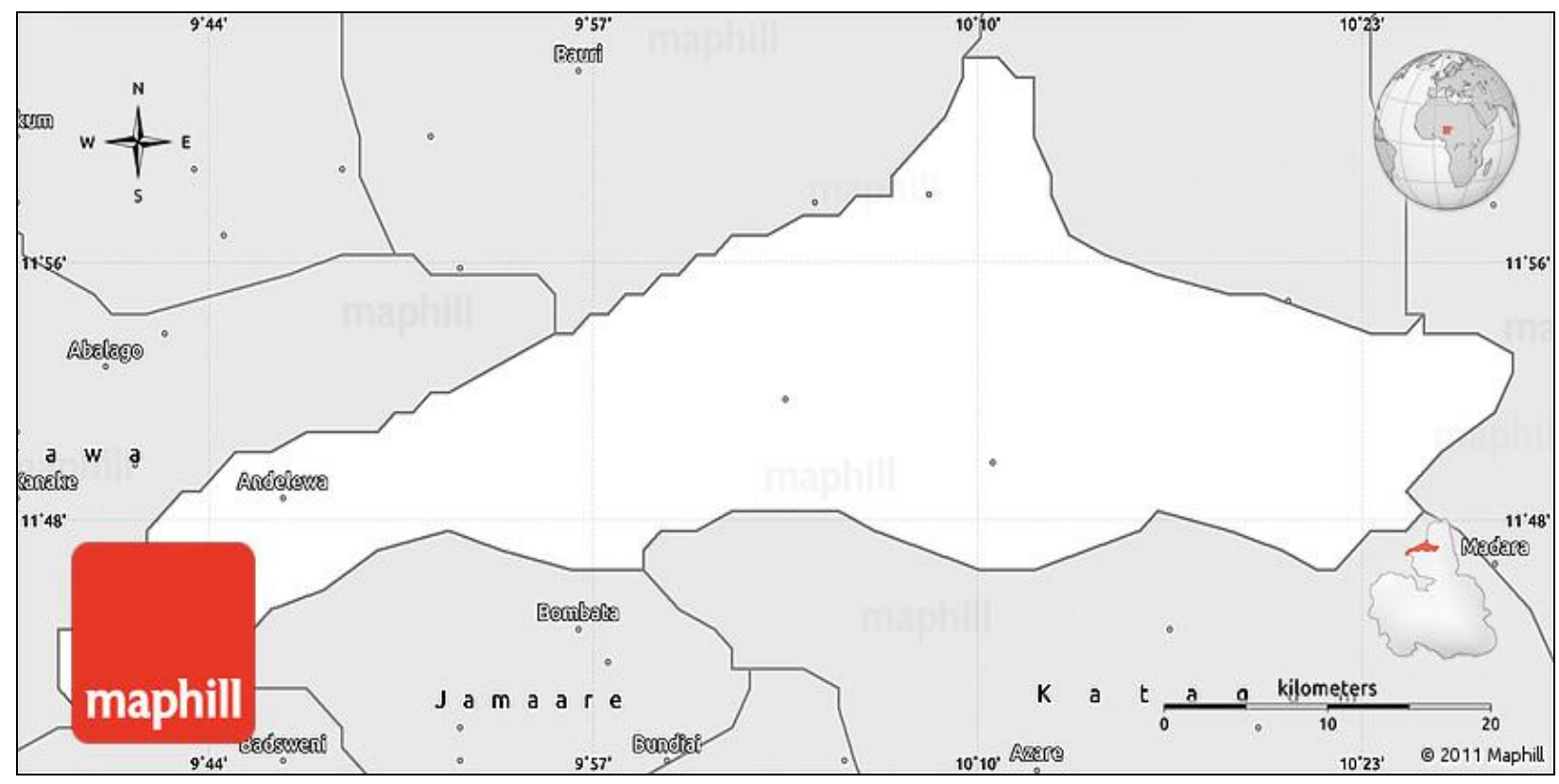

Fig 1: Map of study area, Gadau district, Itas Gadau Local Government Area of Bauchi state.

\section{Sampling methods}

During the research, five farming communities in the Gadau district with possible indigenous termite management practices were randomly selected for the study. Therefore, 100 questionnaires were administered to 100 respondent farmers (20 from each community) on the type of indigenous methods applied in termite control, reasons for the particular indigenous method. The farmers were within the ages of 20 to 65 years and had gained 1 to 30 years of experience in farming and the use of indigenous methods. Thus, years of experience was taken into consideration in order to ascertain the efficacy and problems associated with the use of indigenous methods.

\section{Data collection and analysis}

The study used semi-structured questionnaires and participatory rural appraisal (PRA) approach (farmers directly involved in identification and assessment of termite in infestation in the field). Field surveys were conducted on the plots where indigenous termite management had been applied and field observations of possible distance of termite nest/activity from the treatment spots were measured to ascertain the efficacy of the indigenous methods. The data collected using questionnaires were analyzed using descriptive statistical analysis.

\section{Results \\ Personal data of farmers in the study area}

The majority of the farmers were within the age of 25 to 39 years $(56 \%)$ followed by the 40 to 49 years (43\%) age groups and the farmers with age group 60 above constitute the lowest proportion of respondents among those interviewed $(1 \%)$. The majority of the farmers $(82 \%)$ applied indigenous practice for the management of termite infestations on areas between 1 to 3 acres while $18 \%$ were working on farm sizes of four acres and above.

\section{Termite species diversity and distribution}

Eighty-one (81) species of termite were identified in the study area (Table 1). The genus Termes, Coptotermes, and Glyptotermes were common throughout the study area comprising $80 \%$ of the total. The community of Walai had the highest number of 26 different termite species and the community with the least number was Malumawa with ten species (Table 1). The result affirms that, the number and species of termites vary within a locality. 
Table 1: Termite species and spatial distribution in the study area

\begin{tabular}{|c|c|c|c|c|c|c|}
\hline \multirow{2}{*}{ Genus } & \multirow{2}{*}{ Total NO. OF SPP } & \multicolumn{5}{|c|}{ Specie Distribution in The Community } \\
\cline { 3 - 7 } & & Gadau & Malumawa & Atawari & Walai & Katsinawa \\
\hline Macrotermes & 6 & 1 & 2 & - & 3 & - \\
\hline Glyptotermes & 8 & 3 & 1 & 2 & 1 & 1 \\
\hline Pericaprotermes & 20 & 5 & 3 & 2 & 10 & - \\
\hline Coptotermes & 30 & 6 & 4 & 7 & 10 & 3 \\
\hline Termes & 17 & 2 & 1 & 2 & 2 & 10 \\
\hline Total & 81 & 17 & 10 & 13 & 26 & 14 \\
\hline
\end{tabular}

\section{Termite damage and indigenous management methods}

Crops grown in the study area and most affected by termites infestation included millet, maize, rice, groundnuts and pepper (Table 2). The crops were often observed to be significantly damaged before or after harvest. Though there was no quantitative data on extent of termite damage, the study revealed that the highest crop damage occurred in millet production followed by groundnuts, while other crop damages were minor.
Table 2: Commonly damaged crops by termites in the study area.

\begin{tabular}{|c|c|}
\hline Common name of crop & Scientific name \\
\hline Maize & Zea mays \\
\hline Millet & Pennisetumglaucum \\
\hline Groundnuts & Arachis hypogeal \\
\hline Rice & Oryza sativa \\
\hline Pepper & Capsicum spp. \\
\hline Garden eggs & Solanum melongena \\
\hline
\end{tabular}

The research outcome as indicated in Table 3 revealed five main methods used by farmers in the study area for the control of termite infestations.

Table 3: Indigenous management methods used in the study area

\begin{tabular}{|c|c|c|c|c|c|}
\hline Method used & $\begin{array}{c}\text { Cow urine }+ \text { Pepper } \\
\text { application }\end{array}$ & \begin{tabular}{|c|} 
Direct pouring of \\
water on termite nest
\end{tabular} & $\begin{array}{c}\text { Application of } \\
\text { Chemical (DDT) }\end{array}$ & Wood ash & $\begin{array}{c}\text { Salt in shea butter } \\
\text { residue }\end{array}$ \\
\hline $\begin{array}{l}\text { Frequency of } \\
\text { application }\end{array}$ & Once & Once & Anytime & $\begin{array}{l}\text { Any time before } \\
\text { storage }\end{array}$ & Once \\
\hline Area applied & Farm/House & House & Farm/House & Any where & $\begin{array}{l}\text { Termite nest and } \\
\text { infested field }\end{array}$ \\
\hline Time applied & Rainy Season & Rainy Season & Rainy Season & Any season & Any season \\
\hline $\begin{array}{l}\text { Method of } \\
\text { application }\end{array}$ & $\begin{array}{l}\text { Mixed cow urine and } \\
\text { pepper poured directly } \\
\text { on termite nest/field }\end{array}$ & $\begin{array}{c}\text { Water is poured } \\
\text { directly on termite } \\
\text { nest/field }\end{array}$ & $\begin{array}{c}\text { Chemical eg DDC is } \\
\text { spread directly on } \\
\text { termite nest/field }\end{array}$ & $\begin{array}{c}\text { Spread on floor and } \\
\text { keep harvested } \\
\text { produce on top }\end{array}$ & $\begin{array}{l}\text { Spray in nest/on } \\
\text { field }\end{array}$ \\
\hline $\begin{array}{l}\% \text { of farmer } \\
\text { users }(100)\end{array}$ & $15 \%$ & $20 \%$ & $25 \%$ & $25 \%$ & $15 \%$ \\
\hline
\end{tabular}

\section{Efficacy of the Treatment methods}

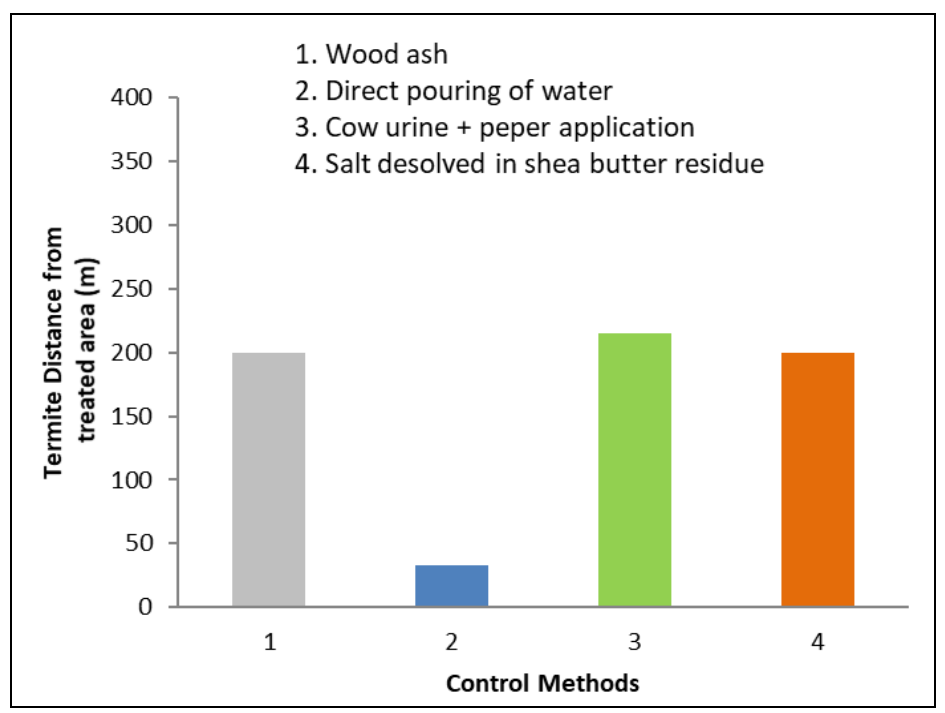

Fig 2: Mean distances of termites/termitaria from fields treated by different indigenous methods.

\section{Discussion}

The distribution of termites species identified in Gadau, Malumawa, Walai, Atawari and Katsinawa as shown in Table 1, shows that eighty one species of termites belonging the genus macrotermes, Glyptotermes, Pericaprotermes, Coptotermes and termes were identified. The highest number of termites identified was found in Walai with a total number of 26 termites, followed by the termites in Gadau with a total number of 17 termites, followed by the termites in Katsinawa with a total number of 14 termites, followed by the termites in Atawari with a total number of 13 termites and the least common species was found in 
Malumawa with a total number of 10 termites.

Although, there was no quantitative data on extent of termite damage, the study revealed that the highest crop damage occurred in millet production followed by groundnut, while other crop damages were minor. High crop damage in millet confirms that the result obtained by farm interviews held with famers in five farming communities in Gadau district $100 \%$ damage by termites can occur in millet production. There was no reported incident of sorghum damage on crop fields during the study thus, confirming the assertion that sorghum is protected from termite damage, perhaps due to its role as a reservoir of termite predatory ants ${ }^{[11,12]}$.

About $55 \%$ of the respondents reported that partial damage occurred in various crops ranging from the seedling to harvest phase but peak damage usually occurred when harvest was delayed with a $100 \%$ possibility of damage occurring in storage facilities for every crop. Direct observations revealed that in the study area termite damage was not limited only to crops but to all sorts of resources such as buildings, farm huts, trees, wood and products.

Most pest species, under favorable conditions, have a high reproductive rate and thus may cause habitat destruction when ensuring their own survival [13]. As such, the availability of suitable food and habitats could have enhanced fecundity for any species of termite pests enabling them to reproduce fast enough to cause enormous destruction. The abundance could as well be attributed to the reduction or absence of natural enemies, such as birds, pangolin, aardvark and amphibians, due to habitat destruction or changes in ecological conditions ${ }^{[14]}$.

The research outcome as indicated in Table 3 revealed five main methods used by farmers in the study area for the control of termite infestations. A single application of any of these methods was said to be enough to protect the field for several seasons, except the wood ash method that required annual application. None of the farmers practiced a combined or an integrated treatment method and it was realized that all the methods they used did not kill termites but some acted as repellents. This may have been intentional, as termites are used by farmers as a cheap source of protein feed for chickens during the first four weeks of the chickens' growth in the area. It could also be partially due to the readily available and accessible planting materials in the study area. Dissolved salt (sodium chloride) in Shea residue was the method least used by farmers (4\%). This could be attributed to cost of the materials for application as salt is primarily used as a cooking ingredient and it is fairly expensive for farmers to purchase in the quantities needed. The results of the questionnaire indicated that the respondents had no clear indication as to the level of control each particular method exerted on their respective fields. However, measurement of termite locations/termitaries from the treatment spots was used to calculate the average distances that the termites were repelled by the various methods (Figure 1). Fields treated with Cow urine + peper application recorded the highest mean distance of $215 \mathrm{~m}$, while fields treated with direct water pouring recorded the lowest average distance of $33 \mathrm{~m}$.

\section{Conclusion}

The existence of 81 species of termites in five localities in Gadau district has serious implication on natural resources especially the presence of the known pest genera such as
Macrotermes and Glyptotermes in the area. Farmers' innovation was evident in the diversity of indigenous termite control methods that were employed in the study area. Five methods of termite control identified in the study area were said to protect the fields for several seasons upon a single application. Reports, direct observations and field measurements gave evidence towards the efficacy of these methods.

\section{Acknowledgment}

Our acknowledgment goes the Department of Biological Science of Bauchi State University for supporting the research and using their labs and museum for termite identification purposes as well as the Staff of the Department for their observations.

\section{References}

1. Sileshi G, Akinnifesi FK, Ajayi OC, Chakeredza S, Mngomba S, Nyoka BI. Towards sustainable management of soil biodiversity in agriculture and landscape in Africa. J. biodiversity, Zambia. 2008; 9:64-67.

2. Eggleton P. Global patterns of termite diversity. Kluwer Academic Publishers, Dordrecht, Netherlands. 2000, 25-51

3. Forsyth J. Agricultural Insects of Ghana. Ghana Universities Press, Accra. 2002, 76-78.

4. UNESCO. Biodiversity Conservation: Traditional Knowledge and Modern Concepts. Proceedings of UNESCO MAB Regional Seminar on Biosphere Reserves For Biodiversity Conservation and Sustainable Development in Anglophone Africa. March, 9-12. Enviro. Protectn. Agency. Accra, Ghana, 1997, 140-146.

5. Nyeko N, Olubayo FM. Participatory assessment of farmers' experience of termite problems in Agroforestry in Tororo district. Agriculture Research and Extension Network. Overseas Development Institute, London, UK. 2005, 143.

6. Fenemore FG, Prakash A. Applied Entomology. Second edition. New Age International (P) Ltd publishers. 2006, 200-203.

7. Gitonga W, Kusewa TM, Ochiel GRS. Comparison of chemical and cultural against termites in Western Kenya. In proceedings of second regional Workshop on Termites Research. March 7-9, Nairobi Kenya. 1995, 169-216.

8. Nair KSS. Tropical Forest Insects Pest: Ecology, Impact, and Management. The Press Syndicate of Cambridge University. New York, 2007, 218-236.

9. Akutse KS, Owusu EO, Afreh-Nuamah K. Perception of farmers' management strategies for termites control in Ghana. J. Appl. Biosci. 2012; 49:3394-3405.

10. Nyeko P, Gareth JE, Day RK, Thomas R. Farmers' knowledge and perceptions of pests in agroforestry with specific reference to Alnus species in Kabale District, Uganda. Crop protection. 2002; 21(10):929-41

11. Sekamatte MB, Latigo OM, Smith AR. The potentials of proteins and sugar based baits to enhance predatory ants and reduce termite damage to maize in Uganda Ugandan J. Crop Protectn. 2001; 20:653-662.

12. Sekamatte MB, Latigo OM, Smith AR. Effects of maize-legume intercrops on termites damage to maize, 
activity of predatory ants and maize yield in Uganda. Ugandan J. Crop Protection. 2003; 22:653:662.

13. Thacker JRM. An Introduction to Arthropods Pest Control. The press Syndicate of the University of Cambridge. 2002, 94-97.

14. Jiru D. Trees with insecticidal properties and indigenous knowledge based on copping mechanism against pest. Dry lands Coordination Group, Addis Ababa, Ethiopia. 2006, 88-91. 